\title{
Acute and Subacute Toxicological Study of the Aqueous Extract of the Stem Bark of Khaya Grandifoliola (Meliaceae) in Wistar Rats
}

\author{
D.S.M. Essama1,*, G.L.N. Otto², G.E. Enow ${ }^{3}$, P. Amang ${ }^{4}$, P.V. Tan ${ }^{1}$ \\ ${ }^{1}$ Department of Animal Biology and Physiology, Faculty of Sciences, University of Yaoundé I, P.O. Box 812, Yaoundé, Cameroon \\ ${ }^{2}$ Department of Life Science, Higher Teachers' Training College, University of Ngaoundéré, P.O. Box 652, Bertoua, Cameroon. \\ ${ }^{3}$ Regional Hospital of Bafoussam, P.O. Box 980, Bafoussam, Cameroon. \\ ${ }^{4}$ Department of Biological Sciences, Faculty of Science, University of Maroua, Maroua, P.O. Box 814, Cameroon.
}

\section{ART ICLE DET A ILS}

Article history:

Received 10 November 2020

Accepted 06 December 2020

Available online 28 December 2020

\section{Keywords:}

Khaya grandifoliola

Acute Toxicity

Subacute Toxicity

Wistar Rats

\begin{abstract}
A B S T R A C T
This study was carried out to investigate the possible toxic effects of the water extract from Khaya grandifoliola stem bark in Wistar rats. The acute assay used 9 females distributed into 3 groups of 3 rats each. A control group received distilled water and the two test groups received by oral gavage a unique dose of the extract at $2000 \mathrm{mg} / \mathrm{kg}$. In subacute assay, 60 rats both sexes were distributed into 6 groups of 10 rats each ( 5 males and 5 females) and received the extract by oral gavage for 28 days consecutively. The tests groups received extract at 250,500 and $1000 \mathrm{mg} / \mathrm{kg}$. The controls and satellite test groups received respectively distilled water and extract at the dose of $1000 \mathrm{mg} / \mathrm{kg}$. Some anthropometrical, hematological and biochemical parameters were measured and histological sections of some organs were realized. $L_{50}$ was superior at $2000 \mathrm{mg} / \mathrm{kg}$ in acute assay. In subacute toxicity assay, Khaya grandifoliola stimulated the haematopoetic and immune function, showed a significant decrease of alanine transaminase, aspartate transaminase and hypocholesterolaemic effects. Histopathology showed the presence of disturbances at the dose of $1000 \mathrm{mg} / \mathrm{kg}$ especially. K. grandifoliola stem bark could possess moderate toxicity at high doses and adequate caution should be exercised in its use in ethnomedicine.
\end{abstract}

\section{Introduction}

Plants which are commonly used in traditional medicine are frequently promoted as natural and, therefore, harmless. This assessment is based on their usage in the treatment of diseases over centuries [1, 2]. The increasing cost, non-availability of modern drugs and limited access to adequate health care have compelled about $80 \%$ of the world population to use traditional pharmacopoeia for primary health care [3]. Therefore, it should be emphasized that the traditional use of any plant for medicinal purposes, by no means, guarantees the safety of such plant. This raises concern about the potential toxic effects resulting from the short-term and long-term use of such medicinal plants. The data of the acute and subchronic toxicity studies on medicinal plants or preparations derived from them should be obtained in order to increase the confidence in their safety to humans, particularly for use in the development of pharmaceuticals [4]. Consequently, in response to public health concerns, research that focuses on deficiencies in the knowledge about medicinal plants and their potential toxicities is highly encouraged by many official medical and scientific organizations $[5,6]$ and by complementary and alternative medicine (CAM) researchers and practitioners [7]. Therefore, evaluating the toxicological effects of any medicinal plant extract intended to be used in animals or humans is a crucial part of its assessment for potential toxic effects.

Khaya grandifoliola, family of Meliaceae, also called African mahogany, Benin Mahogany, Large-leaved Mahogany, or Senegal Mahogany. It is found in Benin, The Democratic Republic of the Congo, Ivory Coast, Ghana, Guinea, Nigeria, Sudan, Cameroun, Togo and Uganda. It is used in the form of concoction for the treatment of convulsion, cough, stomach ache, fever, threatened abortion, rheumatism, dermatomycosis and malaria fever in Nigeria [8-10]. The stem bark of this plant has been scientifically evaluated for some activity. The anti-malaria activity of the stem bark was reported [11-14]. The stem back was also found to possess anti-ulcer property [15], antimicrobial potentials against both gram positive and gram negative

bacteria especially on some resistant strains of Staphylococcus [16], antiinflammatory activity [17], anti-anaemic [18, 19], hypoglycaemic, hyporoteinaemic and hypocholesterolaemic effects [20]. Khaya grandifoliola extract was also reported as possessing the antioxidant activity and hepatoprotective effect $[21,22]$. The phytochemicals tests showed the presence of limonoids, saponines, tannins, alkaloids, anthraquinones, flavonoids, reducing sugars and phlobatannins in these plants [23-25]. Proximate analysis showed that carbohydrate and proteins were higher in K. grandifoliola, and lower concentration of minerals such as magnesium, calcium, sodium, potassium, magnesium, iron and manganese [23]. In spite of the wide ethnotherapeutic applications of the plant, there is no literature information related to the safety limits of Khaya grandifoliola aqueous extract in traditional medicine. Thus, in the present study, we evaluated the oral acute and subacute toxicity of the water extract of the aerial parts of $K$. grandifoliola in rats.

\section{Experimental Methods}

\subsection{Plant Material}

The plant material, fresh stem-bark Khaya grandifoliola, was collected in Mbokam village (Jakiri) in the North-West Region of Cameroon $\left(6^{\circ} 06^{\prime}\right.$ North and $10^{\circ} 39^{\prime}$ East). Botanical identification was done at the National Herbarium in Yaoundé by comparison with existing herbarium specimen No. PM 098/95.

\subsection{Animals}

Adult female Wistar rats (140-150 g) were used for acute toxicity and young Wistar rats of both sexes (85-90 g) were used for subacute toxicity. The female rats were nulliparous and non-pregnant. The animals were raised in the Animal house of the Animal Physiology Laboratory, Faculty of Science, University of Yaoundé I. They were fed with a standard laboratory diet and tap water ad libitum. Each cage contained 3 to 5 rats of the same sex with a bedding of wood shavings, and natural day/night cycles were provided. Environmental conditions were maintained at a temperature of $26^{\circ} \mathrm{C} \pm 2{ }^{\circ} \mathrm{C}$ and a relative humidity of $60 \% \pm 10 \%$. Prior 
authorization for the use of laboratory animals in this study was obtained from the Cameroon National Ethics Committee (Reg.No. FWAIRB00001954). The use, handling and care of animals were done in adherence to the European Convention (Strasbourg, 18.III.1986) for the protection of vertebrate animals used for experimental and other purposes (ETS-123), with particular attention to Part III, articles 7-9.

\subsection{Preparation of Plant Extract}

The dried ground stem-back was extracted in water by boiling $1 \mathrm{~kg}$ in 5 liter of water for 30 minutes. The fresh stem-bark of $K$. grandifoliola was cut up, dried and ground to a powder. One kilogram of dried material was boiled in 5 liters of distilled water for 30 minutes. The extract solution was filtered through Whatman filter paper No. 3. The resulting filtrate was evaporated at $40{ }^{\circ} \mathrm{C}$ using a ventilated oven (Jencons-PLS, UK) to obtain $66.35 \mathrm{~g}$ of a red powder. The extract re-dissolved readily in distilled water which was used as the vehicle.

\subsection{Acute Toxicity Study}

Acute toxicity assay was carried out according to the Organization of Economic Co-operation and Development (OECD) guideline No. 423 for testing of chemicals [26]. The overnight fasted (water ad libitum) female rats were divided into 3 groups of 3 animals each. Animals in the control group received distilled water. The first test group received by oral gavage a unique dose of the extract at $2000 \mathrm{mg} / \mathrm{kg}$ and the second test group (the confirmation group), received the same dose of extract 48 hours later. Neither food nor water was given up to $4 \mathrm{~h}$ after extract administration and the animals were observed closely during this time for any toxicity manifestations. Body weight change, signs of toxicity, behavior and mortality were observed for the initial 24 hours after extract administration and once daily for 14 days. At the end of the experimental period, all rats were sacrificed using an overdose of ether. The animals were quickly dissected and the liver, kidneys, stomach, spleen, lungs, heart and ovaries were excised, weighed and prepared for gross anatomy.

\subsection{Subacute Toxicity Study}

The repeated doses (28 days) procedure for oral toxicity study was carried out in rats according to the OECD test guideline No. 407 [27]. Sixty rats of both sexes were distributed into 6 groups of 10 rats each $(5$ males and 5 females) as follows: Control groups I and II received distilled water, while Groups III to Group VI received, respectively, 250, 500, 1000 and $1000 \mathrm{mg} / \mathrm{kg}$ of extract daily for 28 days. Body weight, food and water intake were measured daily. The animals were observed daily for any death and abnormal clinical signs during the entire study period. At the end of the treatment period, 40 animals (Control I and Groups III, IV \& V) were fasted overnight (water ad libitum). On day 29, the animals were weighed, and sacrificed (one at a time) using an overdose of ether. Each rat was opened up surgically and blood samples were drawn by cardiac puncture. Blood was collected into tubes with and without ethylene diamine tetra acetic acid (EDTA) for hematological and biochemical analysis, respectively. The internal organs such as liver, kidneys, stomach, spleen, lungs, heart and testis/ovaries were excised, prepared for gross pathology and weighed (paired organs were weighed together) to determine relative organs weights. Liver, kidney and lung tissue samples were rinsed in $0.9 \%$ saline and preserved in $10 \%$ neutral buffered formaldehyde solution for histopathological examination. Fourteen days later, the 20 remaining animals (Control II \& Group VI) were sacrificed and submitted to the same procedures as above in order to observe reversibility, persistence or delayed occurrence of toxic effects.
Hematological Parameters: Blood samples were collected into sample tubes containing EDTA. The tubes were shaken gently to mix up the blood with EDTA and prevent clotting. Red blood cell count (RBC), white blood cell count (WBC), differential leukocyte count (lymphocyte, monocyte, granulocyte), platelets, hemoglobin (HGB), hematocrit (HCT), mean corpuscular hemoglobin concentration (MCHC), mean corpuscular hemoglobin $(\mathrm{MCH})$ and mean corpuscular volume (MCV) were determined using an automatic analyzer (Hospitex Diagnostics Hema Screen 18).

Biochemical Parameters: Blood samples collected without anticoagulant were immediately centrifuged at $3400 \mathrm{rpm}$ for $10 \mathrm{~min}$. to obtain serum for analysis of biochemical parameters. The serum was carefully aspirated with a Pasteur pipette into sample bottles for the various biochemical assays. Serum contents of alanine aminotransferase (ALAT), aspartate aminotransferase (ASAT), triglyceride, cholesterol (Chol) (total, HDL and LDL), creatinine, urea, total bilirubin and total protein were evaluated using standard analytical kits from Fortress Diagnostics Ltd, UK. Atherogenic index was calculated as described by authors [28].

Histopathological Examination: Tissues samples of liver, Kidneys and lungs preserved in $10 \%$ neutral buffered formaldehyde solution were dehydrated using upgraded ethanol series and embedded in paraffin blocks. Ultrathin sections $(5 \mu \mathrm{m})$ were dewaxed by xylene, rehydrated through a degraded ethanol series and stained with hematoxylin and eosin (H\&E). A pathologist performed the histopathological examination with an optical microscope and microphotographs of the sections were recorded.

\subsection{Statistical Analysis}

Statistical analysis was done by one-way analysis of variance (ANOVA) followed by the Dunnett's test for multiple comparisons and $p$ values less than 0.05 were considered as significant. The results are expressed as mean \pm standard error of mean (S.E.M).

\section{Results and Discussion}

\subsection{Acute Toxicity}

The limit dose of $2000 \mathrm{mg} / \mathrm{kg}$ did not cause death or any toxic signs in treated rats (females). All rats were normal throughout the study and survived until the end of the 14-days experimental period. No behavioral changes such as tremor, convulsion, self-mutilation, salivation, lethargy or sleep were observed during the first four hours of $K$. grandifoliola extract administration. No changes in feces and body coat condition and reactivity to noise and touch were observed. The eating and drinking habits of all the animals remained normal, and there were no significant differences in body and organs weights of rats treated with the extract compared with the controls. Macroscopic examination did not reveal any changes in organ condition.

\subsection{Subacute Toxicity}

No behavioural changes (in locomotors activity, no ataxia, and no signs of intoxication) and death were observed at the end of the treatment period. Similarly, no significant differences in food intake and weight gain (Table 1) were observed between control and treated groups during this period. The relative organs weights showed no significant differences between treated and control groups (Table 2). The macroscopic observation of the target organs (liver, lung, heart, spleen, kidney and sex organs) of the treated animals did not show significant changes in color and texture when compared with the controls.

Table 1 Effects of K. grandifoliola on the body weight (g) in subacute assay

\begin{tabular}{|c|c|c|c|c|c|c|c|c|}
\hline & Dose (mg/kg) & Day 1 & Day 7 & Day 14 & Day 21 & Day 28 & Day 35 & Day 42 \\
\hline \multicolumn{9}{|l|}{$\overline{\text { Male }}$} \\
\hline Control I & - & $131.9 \pm 07.2$ & $145.3 \pm 08.1$ & $156.2 \pm 08.7$ & $175.3 \pm 10.6$ & $180.8 \pm 11.3$ & - & - \\
\hline Control II & - & $151.1 \pm 11.3$ & $180.4 \pm 12.2$ & $189.1 \pm 12.4$ & $195.8 \pm 11.0$ & $210.3 \pm 12.7$ & $219.6 \pm 13.2$ & $225 \pm 12.2$ \\
\hline Group III & 250 & $147.7 \pm 08.0$ & $155.0 \pm 06.5$ & $174.6 \pm 02.3$ & $183.1 \pm 0.92$ & $195.1 \pm 08.7$ & - & - \\
\hline Group IV & 500 & $141.0 \pm 13.4$ & $152.1 \pm 13.8$ & $163.4 \pm 15.9$ & $177.4 \pm 19.7$ & $186.7 \pm 18.4$ & - & - \\
\hline Group V & 1000 & $149.2 \pm 10.3$ & $160.5 \pm 08.3$ & $169.5 \pm 06.8$ & $178.4 \pm 06.3$ & $174.6 \pm 09.1$ & - & - \\
\hline Group VI & 1000 & $131.1 \pm 15.7$ & $158.7 \pm 18.8$ & $162.3 \pm 18.9$ & $175.2 \pm 17.5$ & $188.0 \pm 15.8$ & $203.6 \pm 15.9$ & $211 \pm 14.4$ \\
\hline \multicolumn{9}{|l|}{ Female } \\
\hline Control I & - & $118.0 \pm 6.2$ & $123.2 \pm 7.3$ & $130.1 \pm 6.2$ & $141.3 \pm 9.3$ & $151.8 \pm 8.5$ & - & - \\
\hline Control II & - & $101.5 \pm 2.2$ & $124.7 \pm 2.2$ & $136.9 \pm 2.2$ & $143.1 \pm 1.7$ & $157.0 \pm 1.9$ & $166.7 \pm 5.9$ & $166.6 \pm 9.0$ \\
\hline Group III & 250 & $119.2 \pm 5.4$ & $130.8 \pm 5.2$ & $140.8 \pm 5.8$ & $154.3 \pm 5.8$ & $169.0 \pm 4.7$ & - & - \\
\hline Group IV & 500 & $124.6 \pm 7.9$ & $126.9 \pm 7.7$ & $134.4 \pm 9.4$ & $144.5 \pm 7.0$ & $157.2 \pm 6.4$ & - & - \\
\hline Group V & 1000 & $132.0 \pm 4.7$ & $142.0 \pm 1.6$ & $147.3 \pm 4.4$ & $154.1 \pm 5.4$ & $162.5 \pm 3.0$ & - & - \\
\hline Group VI & 1000 & $106.4 \pm 6.3$ & $125.1 \pm 7.6$ & $127.9 \pm 8.3$ & $134.1 \pm 9.8$ & $141.1 \pm 10$ & $151.8 \pm 10.8$ & $153.6 \pm 1.0$ \\
\hline
\end{tabular}

Values are expressed as mean \pm S.E.M. $(n=5)$ 
Table 2 Effects of $K$. grandifoliola on the relative organ weights (g/100 g of b.w.) in subacute assay

\begin{tabular}{|c|c|c|c|c|c|c|c|}
\hline & Heart & Lungs & Liver & Stomach & Spleen & Kidneys & Testis/Ovaries \\
\hline \multicolumn{8}{|l|}{$\overline{\text { Male }}$} \\
\hline Control I & $0.35 \pm 0.02$ & $0.93 \pm 0.12$ & $2.86 \pm 0.13$ & $0.79 \pm 0.04$ & $0.41 \pm 0.08$ & $0.72 \pm 0.04$ & $1.40 \pm 0.18$ \\
\hline Control II & $0.32 \pm 0.01$ & $0.86 \pm 0.06$ & $2.71 \pm 0.18$ & $0.82 \pm 0.04$ & $0.33 \pm 0.02$ & $0.5 \pm 0.02$ & $1.30 \pm 0.03$ \\
\hline $250 \mathrm{mg} / \mathrm{kg}$ & $0.35 \pm 0.01$ & $0.77 \pm 0.06$ & $2.79 \pm 0.15$ & $0.86 \pm 0.03$ & $0.46 \pm 0.03$ & $0.63 \pm 0.03$ & $1.50 \pm 0.03$ \\
\hline $500 \mathrm{mg} / \mathrm{kg}$ & $0.35 \pm 0.02$ & $1.12 \pm 0.16$ & $2.94 \pm 0.08$ & $0.88 \pm 0.05$ & $0.36 \pm 0.02$ & $0.64 \pm 0.04$ & $1.50 \pm 0.16$ \\
\hline $1000 \mathrm{mg} / \mathrm{kg}$ & $0.34 \pm 0.01$ & $0.90 \pm 0.13$ & $2.71 \pm 0.25$ & $0.90 \pm 0.02$ & $0.29 \pm 0.00$ & $0.66 \pm 0.02$ & $1.64 \pm 0.11$ \\
\hline $1000 \mathrm{mg} / \mathrm{kg}$ & $0.33 \pm 0.03$ & $0.91 \pm 0.04$ & $2.88 \pm 0.15$ & $0.85 \pm 0.05$ & $0.31 \pm 0.03$ & $0.58 \pm 0.03$ & $1.33 \pm 0.05$ \\
\hline \multicolumn{8}{|l|}{ Female } \\
\hline Control I & $0.44 \pm 0.03$ & $0.96 \pm 0.12$ & $3.41 \pm 0.08$ & $0.91 \pm 0.03$ & $0.32 \pm 0.05$ & $0.76 \pm 0.05$ & $0.10 \pm 0.02$ \\
\hline Control II & $0.40 \pm 0.04$ & $0.90 \pm 0.05$ & $3.03 \pm 0.09$ & $0.90 \pm 0.02$ & $0.31 \pm 0.03$ & $0.58 \pm 0.03$ & $0.08 \pm 0.01$ \\
\hline $250 \mathrm{mg} / \mathrm{kg}$ & $0.38 \pm 0.02$ & $0.85 \pm 0.07$ & $3.18 \pm 0.08$ & $0.87 \pm 0.03$ & $0.39 \pm 0.04$ & $0.62 \pm 0.02$ & $0.06 \pm 0.02$ \\
\hline $500 \mathrm{mg} / \mathrm{kg}$ & $0.38 \pm 0.03$ & $0.97 \pm 0.10$ & $3.04 \pm 0.04$ & $0.97 \pm 0.02$ & $0.65 \pm 0.02$ & $0.68 \pm 0.02$ & $0.10 \pm 0.01$ \\
\hline $1000 \mathrm{mg} / \mathrm{kg}$ & $0.38 \pm 0.02$ & $1.01 \pm 0.10$ & $3.09 \pm 0.20$ & $0.97 \pm 0.02$ & $0.43 \pm 0.06$ & $0.65 \pm 0.01$ & $0.10 \pm 0.01$ \\
\hline $1000 \mathrm{mg} / \mathrm{kg}$ & $0.37 \pm 0.03$ & $0.77 \pm 0.03$ & $2.69 \pm 0.05$ & $0.79 \pm 0.04$ & $0.31 \pm 0.02$ & $0.57 \pm 0.02$ & $0.07 \pm 0.01$ \\
\hline
\end{tabular}

Values are expressed as mean \pm S.E.M. $(n=5)$

Table 3 Effects of $K$. grandifoliola on hematological parameters in subacute toxicity

\begin{tabular}{|c|c|c|c|c|c|c|}
\hline & $\begin{array}{l}\text { Control I } \\
\left(\mathrm{dH}_{2} \mathrm{O}\right)\end{array}$ & $\begin{array}{l}\text { Group I } \\
(250 \mathrm{mg} / \mathrm{kg})\end{array}$ & $\begin{array}{l}\text { Group II } \\
(500 \mathrm{mg} / \mathrm{kg})\end{array}$ & $\begin{array}{l}\text { Group III } \\
(1000 \mathrm{mg} / \mathrm{kg})\end{array}$ & $\begin{array}{l}\text { Control II } \\
\left(\mathrm{dH}_{2} \mathrm{O}\right)\end{array}$ & $\begin{array}{l}\text { Group IV } \\
(1000 \mathrm{mg} / \mathrm{k})\end{array}$ \\
\hline \multicolumn{7}{|l|}{ Male } \\
\hline $\operatorname{RBC}\left(10^{6} / \mu \mathrm{L}\right)$ & $5.83 \pm 0.06$ & $7.26 \pm 0.16^{*}$ & $6.38 \pm 0.17$ & $5.83 \pm 0.60$ & $5.48 \pm 0.08$ & $5.04 \pm 0.36$ \\
\hline WBC $\left(10^{3} / \mu \mathrm{L}\right)$ & $4.27 \pm 0.09$ & $3.85 \pm 0.03$ & $3.5 \pm 0.67$ & $3.57 \pm 0.28$ & $4.67 \pm 0.13$ & $4.57 \pm 0.09$ \\
\hline Lymphocyte (\%) & $90.1 \pm 0.06$ & $86.53 \pm 1.42$ & $79.37 \pm 5.14$ & $82.47 \pm 5.38$ & $90.7 \pm 0.94$ & $93.7 \pm 1.91$ \\
\hline Monocyte (\%) & $6.8 \pm 0.06$ & $6.57 \pm 0.72$ & $10.10 \pm 1.78$ & $10.13 \pm 2.95$ & $6.13 \pm 0.89$ & $6 \pm 0.81$ \\
\hline Granulocyte (\%) & $3.2 \pm 0.00$ & $6.9 \pm 0.12^{*}$ & $10.5 \pm 1.1^{* * *}$ & $10.0 \pm 0.8^{* * *}$ & $3.2 \pm 0.21$ & $4.67 \pm 0.55$ \\
\hline Platelets $\left(10^{3} / \mu \mathrm{L}\right)$ & $594.0 \pm 0.6$ & $1098 \pm 38^{* * *}$ & $546.7 \pm 77.0$ & $462.7 \pm 45.5$ & $398 \pm 37.9$ & $854 \pm 54.3^{\# \#}$ \\
\hline $\mathrm{HGB}(\mathrm{g} / \mathrm{dL})$ & $13.4 \pm 0.13$ & $9.3 \pm 1.37$ & $11.23 \pm 1.34$ & $13.73 \pm 0.02$ & $8.53 \pm 2.4$ & $13.17 \pm 0.74$ \\
\hline HCT (\%) & $32.8 \pm 0.06$ & $48.00 \pm 4.97^{*}$ & $36.27 \pm 2.30$ & $34.57 \pm 2.11$ & $31.8 \pm 1.62$ & $34.09 \pm 2.92$ \\
\hline MCHC (g/dL) & $23.57 \pm 0.03$ & $18.47 \pm 0.72$ & $20.13 \pm 1.8$ & $24.37 \pm 2.05$ & $23.6 \pm 0.04$ & $31 \pm 0.78^{\# \# \#}$ \\
\hline MCH (pg) & $55.7 \pm 0.33$ & $65.67 \pm 5.49$ & $85.67 \pm 17.33$ & $53.67 \pm 3.76$ & $71 \pm 6.66$ & $70.5 \pm 3.75$ \\
\hline MCV (fL) & $5.83 \pm 0.06$ & $7.26 \pm 0.16^{*}$ & $6.38 \pm 0.17$ & $5.83 \pm 0.60$ & $5.48 \pm 0.08$ & $5.04 \pm 0.36$ \\
\hline \multicolumn{7}{|l|}{ Female } \\
\hline $\operatorname{RBC}\left(10^{6} / \mu \mathrm{L}\right)$ & $5.54 \pm 1.02$ & $5.83 \pm 0.70$ & $7.33 \pm 0.02$ & $4.60 \pm 0.83$ & $3.99 \pm 1.33$ & $1.83 \pm 0.32$ \\
\hline $\mathrm{WBC}\left(10^{3} / \mu \mathrm{L}\right)$ & $3.8 \pm 0.06$ & $5.33 \pm 0.84$ & $5.53 \pm 0.67$ & $5.50 \pm 0.80$ & $5.1 \pm 0.15$ & $7.05 \pm 0.49$ \\
\hline Lymphocyte (\%) & $80.35 \pm 10.0$ & $76.33 \pm 3.92$ & $77.40 \pm 1.50$ & $79.87 \pm 0.15$ & $85.33 \pm 4.2$ & $75.9 \pm 3.17$ \\
\hline Monocyte (\%) & $6.57 \pm 0.47$ & $17.17 \pm 5.97$ & $12.3 \pm 0.29$ & $9.97 \pm 0.19$ & $10.0 \pm 2.9$ & $9.4 \pm 0.36$ \\
\hline Granulocyte (\%) & $2.5 \pm 0.12$ & $8.50 \pm 0.12^{* *}$ & $10.5 \pm 1.96^{* *}$ & $10.20 \pm 0.0^{* *}$ & $6.6 \pm 0.51$ & $13.37 \pm 0.8^{\# \#}$ \\
\hline Platelets $\left(10^{3} / \mu \mathrm{L}\right)$ & $676.3 \pm 51.3$ & $629.7 \pm 62.1$ & $596 \pm 45.72$ & $328 \pm 42.7^{* * *}$ & $701 \pm 88$ & $460 \pm 124$ \\
\hline $\mathrm{HGB}(\mathrm{g} / \mathrm{dL})$ & $13.67 \pm 0.5$ & $14.47 \pm 0.27$ & $14.97 \pm 0.32$ & $10.83 \pm 1.60$ & $12.0 \pm 1.13$ & $9.37 \pm 0.15$ \\
\hline HCT (\%) & $30.7 \pm 2.71$ & $34.13 \pm 2.14$ & $41.4 \pm 0.37$ & $25.45 \pm 4.36$ & $25.4 \pm 7.0$ & $12.80 \pm 0.64$ \\
\hline MCHC (g/dL) & $27.70 \pm 4.13$ & $25.6 \pm 3.30$ & $20.4 \pm 0.46$ & $42.57 \pm 10.70$ & $35.40 \pm 8.6$ & $86.20 \pm 26.1$ \\
\hline MCH (pg) & $59 \pm 5.76$ & $59.67 \pm 4.18$ & $56.50 \pm 0.29$ & $63 \pm 1.16$ & $65.7 \pm 6.2$ & $74.33 \pm 10.6$ \\
\hline MCV (fL) & $5.54 \pm 1.02$ & $5.83 \pm 0.70$ & $7.33 \pm 0.02$ & $4.60 \pm 0.83$ & $3.99 \pm 1.33$ & $1.83 \pm 0.32$ \\
\hline
\end{tabular}

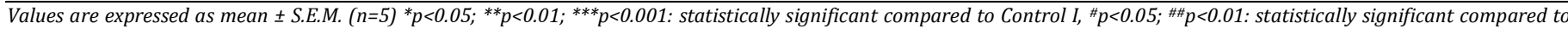
control II; \#\# $p<0.001$ : statistically significant compared to control II

Table 4 Effects of $K$. grandifoliola on biochemical parameters in subacute toxicity

\begin{tabular}{|c|c|c|c|c|c|c|}
\hline & $\begin{array}{l}\text { Control I } \\
\left(\mathrm{dH}_{2} \mathrm{O}\right)\end{array}$ & $\begin{array}{l}\text { Group I } \\
(250 \mathrm{mg} / \mathrm{kg})\end{array}$ & $\begin{array}{l}\text { Group II } \\
(500 \mathrm{mg} / \mathrm{kg})\end{array}$ & $\begin{array}{l}\text { Group III } \\
(1000 \mathrm{mg} / \mathrm{kg})\end{array}$ & $\begin{array}{l}\text { Control II } \\
\left(\mathrm{dH}_{2} \mathrm{O}\right)\end{array}$ & $\begin{array}{l}\text { Group IV } \\
(1000 \mathrm{mg} / \mathrm{kg})\end{array}$ \\
\hline \multicolumn{7}{|l|}{ Male } \\
\hline ALAT (U/L) & $55.95 \pm 10.49$ & $40.47 \pm 3.38$ & $34.80 \pm 3.54$ & $11.70 \pm 4.42^{* *}$ & $73.20 \pm 44.3$ & $95.15 \pm 38.45$ \\
\hline ASAT (U/L) & $195.10 \pm 2.74$ & $156.30 \pm 9.32$ & $149.20 \pm 22.50$ & $117.80 \pm 22.99^{*}$ & $208.8 \pm 13.2$ & $268.20 \pm 24.13$ \\
\hline Total Chol (mg/dL) & $91.82 \pm 1.54$ & $111.40 \pm 7.86$ & $81.02 \pm 6.51$ & $85.03 \pm 3.77$ & $119.6 \pm 14.3$ & $99.38 \pm 5.71$ \\
\hline Triglyceride (mg/dL) & $48.88 \pm 0.61$ & $53.40 \pm 6.87$ & $31.82 \pm 11.27$ & $44.71 \pm 10.11$ & $48.18 \pm 4.27$ & $39.06 \pm 6.64$ \\
\hline HDL-Chol (mg/dL) & $51.52 \pm 4.68$ & $72.75 \pm 3.57^{*}$ & $45.68 \pm 0.96$ & $45.30 \pm 7.81$ & $41.87 \pm 5.21$ & $48.98 \pm 4.91$ \\
\hline LDL-Chol (mg/dL) & $30.52 \pm 5.10$ & $28.09 \pm 4.97$ & $28.97 \pm 8.41$ & $30.79 \pm 9.00$ & $63.52 \pm 11.4$ & $42.59 \pm 6.80$ \\
\hline Atherogenic index & $1.84 \pm 0.21$ & $1.53 \pm 0.04$ & $1.78 \pm 0.16$ & $1.66 \pm 0.11$ & $2.59 \pm 0.20$ & $2.06 \pm 0.19$ \\
\hline Creatinine (mg/dL) & $0.87 \pm 0.20$ & $0.36 \pm 0.06$ & $0.34 \pm 0.30$ & $0.58 \pm 0.10$ & $0.65 \pm 0.20$ & $0.60 \pm 0.23$ \\
\hline Total bilirubin (mg/dL) & $1.38 \pm 0.44$ & $1.21 \pm 0.09$ & $0.89 \pm 0.33$ & $1.00 \pm 0.08$ & $3.51 \pm 1.68$ & $1.89 \pm 0.63$ \\
\hline Total protein $(\mathrm{mg} / \mathrm{dL})$ & $1.90 \pm 0.11$ & $2.56 \pm 0.11^{*}$ & $1.88 \pm 0.11$ & $1.48 \pm 0.17$ & $2.03 \pm 0.12$ & $1.82 \pm 0.20$ \\
\hline \multicolumn{7}{|l|}{ Female } \\
\hline ALAT (U/L) & $117.00 \pm 5.45$ & $18.7 \pm 1.6^{* * *}$ & $36.73 \pm 5.65^{* * *}$ & $20.05 \pm 5.81^{* * *}$ & $28.10 \pm 2.38$ & $41.87 \pm 0.53$ \\
\hline $\operatorname{ASAT}(\mathrm{U} / \mathrm{L})$ & $129.7 \pm 22.9$ & $63.2 \pm 18.2^{* *}$ & $146.20 \pm 14.21$ & $142.0 . \pm 5.04$ & $195.7 \pm 29.6$ & $183.7 \pm 53.03$ \\
\hline Total Chol (mg/dL) & $89.20 \pm 0.47$ & $82.10 \pm 6.25$ & $74.07 \pm 1.46$ & $68.06 \pm 0.92$ & $75.46 \pm 3.80$ & $70.99 \pm 1.25$ \\
\hline Triglyceride (mg/dL) & $53.14 \pm 7.11$ & $64.74 \pm 2.13$ & $51.26 \pm 8.72$ & $29.44 \pm 3.94^{*}$ & $31.13 \pm 5.08$ & $30.73 \pm 0.34$ \\
\hline HDL-Chol (mg/dL) & $49.49 \pm 4.33$ & $50.25 \pm 4.80$ & $55.21 \pm 2.65$ & $48.35 \pm 0.96$ & $41.87 \pm 5.21$ & $49.11 \pm 4.91$ \\
\hline LDL-Chol (mg/dL) & $29.08 \pm 3.81$ & $21.40 \pm 3.92$ & $16.12 \pm 1.23^{*}$ & $16.32 \pm 2.10^{*}$ & $13.90 \pm 4.63$ & $15.73 \pm 4.55$ \\
\hline Atherogenic index & $1.85 \pm 0.17$ & $1.72 \pm 0.30$ & $1.35 \pm 0.09$ & $1.42 \pm 0.07$ & $1.37 \pm 0.09$ & $1.49 \pm 0.16$ \\
\hline Creatinine (mg/dL) & $0.65 \pm 0.15$ & $0.98 \pm 0.11$ & $0.49 \pm 0.15$ & $0.43 \pm 0.13$ & $0.51 \pm 0.21$ & $1.0 \pm 0.18$ \\
\hline Total bilirubin $(\mathrm{mg} / \mathrm{dL})$ & $5.65 \pm 1.78$ & $2.35 \pm 0.68$ & $3.09 \pm 0.81$ & $2.16 \pm 0.64$ & $3.16 \pm 0.64$ & $2.82 \pm 0.87$ \\
\hline Total protein (mg/dL) & $2.05 \pm 0.22$ & $2.09 \pm 0.20$ & $1.82 \pm 0.20$ & $1.77 \pm 0.07$ & $1.85 \pm 0.10$ & $1.90 \pm 0.20$ \\
\hline
\end{tabular}

Values are expressed as mean \pm S.E.M. $(n=5){ }^{*} p<0.05 ;{ }^{* *} p<0.0 ; 1^{* * *} p<0.001$ : statistically significant compared to control I 
Hematological parameters such as WBC, HGB, lymphocyte, monocyte and $\mathrm{MCH}$ in both control and experimental rats, were not significantly different. Except granulocytes counts whose increase significantly in all the animals to treat of extract at different dose. Also, in male rats, platelet counts showed a significant increase at the dose of $250 \mathrm{mg} / \mathrm{kg}$ and 1000 $\mathrm{mg} / \mathrm{kg}$ (group VI). At the same, the parameters like RBC, HCT and MCV also showed a significant increase at $250 \mathrm{mg} / \mathrm{kg}$ compared with the control (group I) and MCHC at the dose of $1000 \mathrm{mg} / \mathrm{kg}$ (group VI). In female, all the other parameters didn't show a significant variation, except platelet counts that showed significant decrease at the dose $1000 \mathrm{mg} / \mathrm{kg}$ (Table 3).

The results of biochemical parameters in rats treated with various doses of the aqueous extract of $K$. grandifoliola for 28 days are shown in Table 4. In the extract-treated rats, the parameters like ALAT and ASAT decrease significantly only at the dose 1000 at the males; when at the females, ALAT decrease very significantly at all the dose and ASAT only at the dose of $250 \mathrm{mg} / \mathrm{kg}$ of $K$. grandifoliola respectively. The male rats showed at the dose of $250 \mathrm{mg} / \mathrm{kg}$ a light increase of HDL-cholesterol and total protein values, while the female showed a significant decrease of triglycerides (at the dose of $1000 \mathrm{mg} / \mathrm{kg}$ of extract) and LDL (at the dose of 500 and $1000 \mathrm{mg} / \mathrm{kg}$ ).

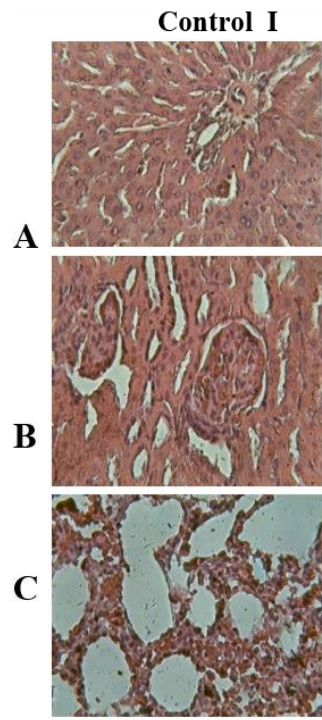

$1000 \mathrm{mg} / \mathrm{kg}$

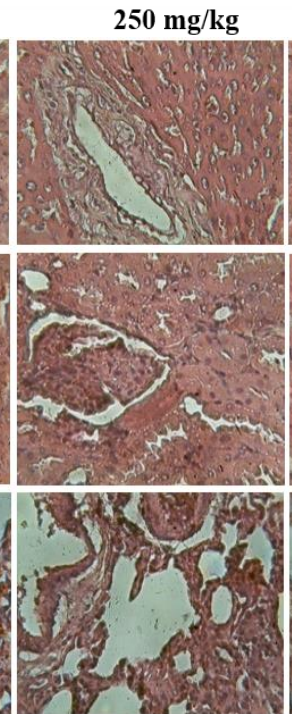

Control II
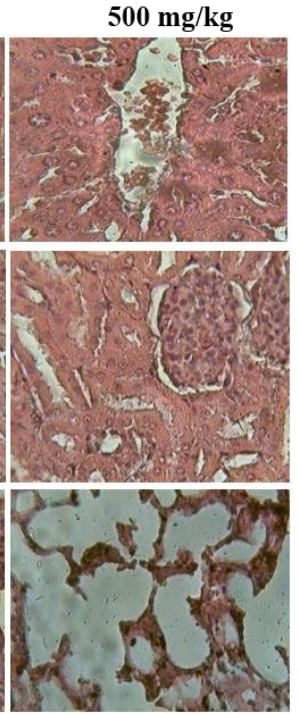

$1000 \mathrm{mg} / \mathrm{kg}$

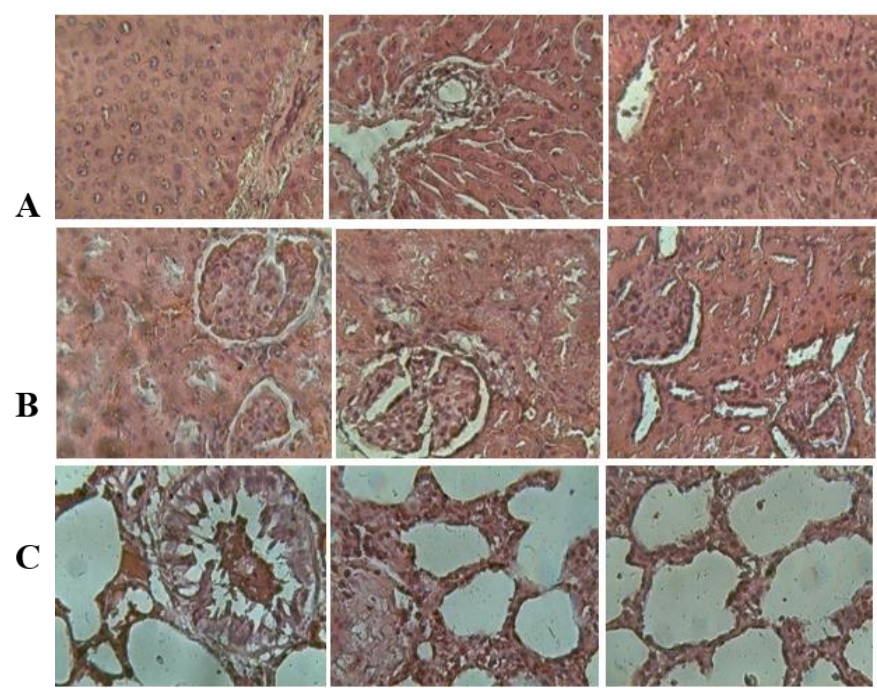

Fig. 1 Effects of $K$. grandifoliola on histology of liver (A), kidneys (B) and lungs (C) in female rats $(\mathrm{H} \& \mathrm{E} \times 10)$

Histology of the lung sections of control rats and of all the extracttreated groups revealed a normal architecture with bronchioles, thinwalled alveoli and alveolar sacs. At dose $250 \mathrm{mg} / \mathrm{kg}$, the male and female lung shown any reactive lesion at this dose. Female lung shows alveolar coalescence and male lung shows congestion shown by dilated blood filled vessels is present in the lungs of animals at $500 \mathrm{mg} / \mathrm{kg}$ dose. At 1000 $\mathrm{mg} / \mathrm{kg}$ dose, lung congestion persists and is exaggerated and complicated by interstitial hemorrhagic foci in both sexes. There is a marked reversal of congestion and hemorrhage to near normal in male and female lungs with satellite control at $1000 \mathrm{mg} / \mathrm{kg}$ dose (Figs. 1 and 2).

https://doi.org/10.30799/jpmr.051.20050106
Histology of the liver sections of control (I \& II) rats showed normal hepatic architecture and normal liver lobular structure with portal triad, prominent nucleus and well-preserved cytoplasm. At 250 and $500 \mathrm{mg} / \mathrm{kg}$ dose no effect on the lesions in the liver. The $1000 \mathrm{mg} / \mathrm{kg}$ dose shown centrilobular chronic persistent inflammatory reaction is seen in the liver in both sexes by presence of inflammatory cells limited by limiting plates to the centrilobular area. Satellite control reverses the pathological changes in the liver of the both sex at $1000 \mathrm{mg} / \mathrm{kg}$ dose, because has no effect on the lesions in the liver at $1000 \mathrm{mg} / \mathrm{kg}$ dose (control II) (Figs. 1 and 2). There are no significant histological lesions observed in the kidney of both male and female rats at 250, 500 and $1000 \mathrm{mg} / \mathrm{kg}$ doses (Figs. 1 and 2).
Control I
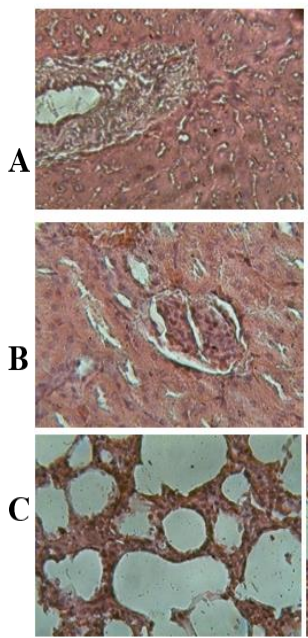

$1000 \mathrm{mg} / \mathrm{kg}$
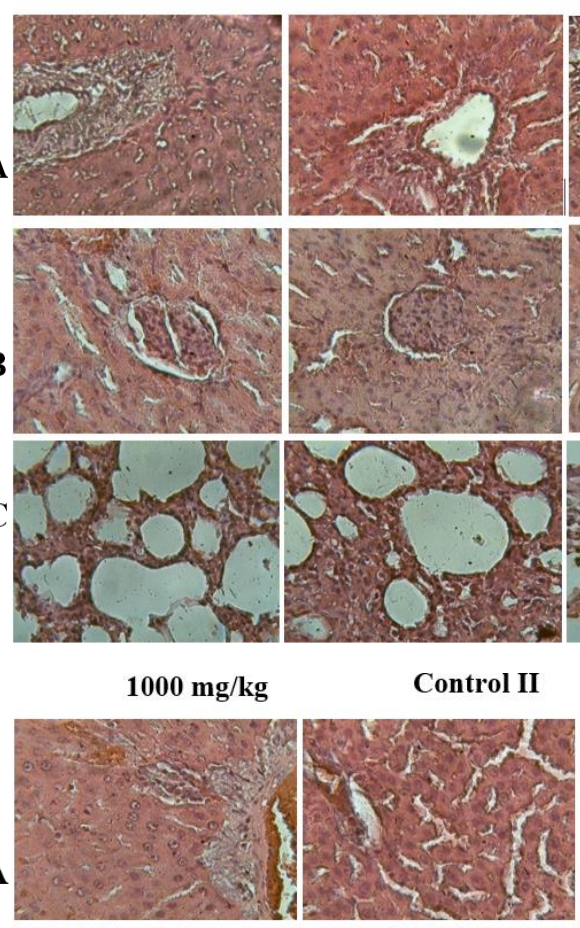

Control II
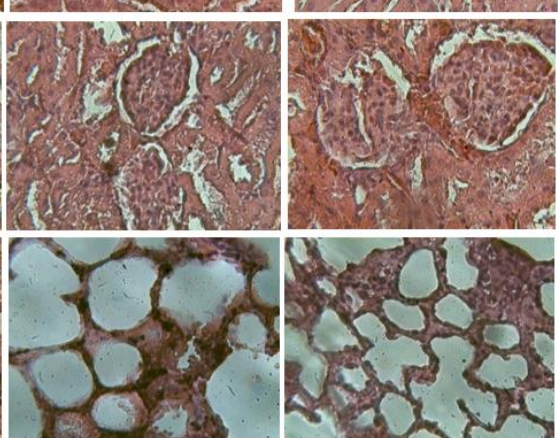

$500 \mathrm{mg} / \mathrm{kg}$
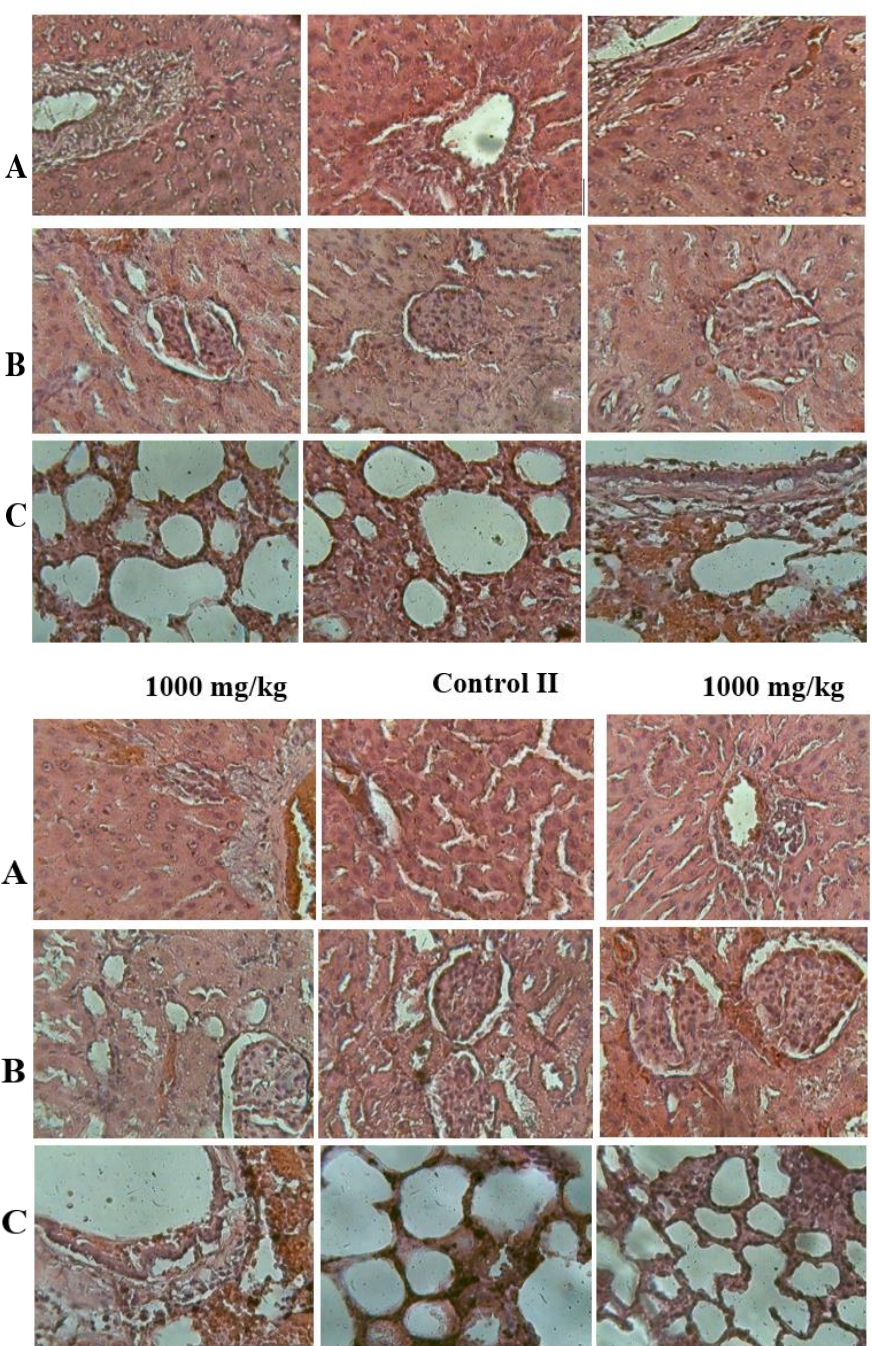

Fig. 2 Effects of $K$. grandifoliola on histology of liver (A), kidneys (B) and lungs (C) in male rats $(\mathrm{H} \& \mathrm{E} \times 10)$

Toxicological investigation of an unknown substance. The index for the acute toxicity is the LD50. The results in this study showed that the acute administration of the aqueous extract of $K$. grandifoliola at the dose of $2000 \mathrm{mg} / \mathrm{kg}$ did not produce any sign of acute toxicity or instant death in rats tested during the period of observation. This, however, suggest that the $\mathrm{LD}_{50}$ of the extract is greater than $2000 \mathrm{mg}$ extract/ $\mathrm{kg}$ of body weight. There were no significant differences in organ and body weights in the extract-treated groups compared with the control. In line with the chemical labelling and classification of acute systemic toxicity. The aqueous extract of $K$. grandifoliola can be assigned to the lowest toxicity class (class 5; no label; unclassified) [26] and to be considered nontoxic at acute administration since the extracts were well tolerated and there was no observed adverse effect.

Acute toxicity data are of limited clinical application since cumulative toxic effects do occur even at very low doses. Hence multiple dose studies are almost always essential in evaluating the safety profile of phytomedicines. Thus, sub-acute toxicity study was carried out for evaluation of long-term effects of the water extract of $K$. grandifoliola. The study revealed that no adverse clinical sign or toxicity sign or death was observed throughout the treatment duration of 28 days in the rats. This is in line with the acute toxicity studies where experimental animals treated orally with the extract doses up to $2000 \mathrm{mg} / \mathrm{kg}$ body weight showed 
neither toxicity sign nor death in mice. This may be an indication that longterm oral administration of the extract within this doses range may be safe. Changes in body weight (especially weight loss) have been used as an indicator of adverse effects of drugs and chemicals [29]. There were no significant changes in animal behaviour, food and water consumptions and in body weight gain in $K$. grandifolila-treated group at any dosage. Macroscopic observation of the major organs showed no abnormalities in morphology consistency and appearance in the rats treated for 28 days with the extract.

Assessment of hematological parameters can be used to determine the extent of deleterious effect of foreign compounds including plant extracts on the blood constituents of an animal. It can also be used to explain blood relating functions of chemical compounds and plant extracts [30]. Such analysis is relevant to risk evaluation as the change in hematological system has higher predictive value for human toxicity, when the data are translated from animal studies. The various blood cells (erythrocytes, leucocytes and platelets) produced at a turnover rate of about 1 to 3 million per second in a healthy human adult and this value could be altered in certain physiological or pathological states [31]. The results of the hematological parameters of the present study showed that, in the males rates, the administration of the aqueous extract of Khaya grandifoliola after 28 days induced a significant increase of: platelet counts at the dose of $250 \mathrm{mg} / \mathrm{kg}$ and $1000 \mathrm{mg} / \mathrm{kg}$; RBC, HCT and MCV at $250 \mathrm{mg} / \mathrm{kg}$ of extract; MCHC at the dose of $1000 \mathrm{mg} / \mathrm{kg}$ and granulocytes counts in all the animals to treat of extract at different dose. The increase in erythrocytes RBC, MCH, MCHC, MCV and HCT after the 28 day study may be due to over production of haematopoietic regulatory elements such as colonystimulating factors, erythropoietin and thrombopoietin by the stroma cells and macrophages in the bone marrowthus providing the local environment for haematopoiesis [32]. Since MCHC, MCH and MCV relate to individual RBCs, while HCT, RBC and PCV relate to the total population of RBCs in the blood [33], it could encourage haemoglobin incorporation into RBCs and a consequent increase in oxygen exchange. MCV reflects the size of RBCs. The MCH and MCHC reflect the haemoglobin content of RBCs. The result of this study showed the stimulation of the hematopoietic system, leading to the production of RBC (erythropoiesis) which boost the immune system and platelets [31]. The most relevant cells involved in the immune response are lymphocytes, but other cells are also implicated, including monocytes/macrophages and polimorphonuclear granulocytes [34]. Leukocytosis (granulocytes) observed in all the Group is a normal reaction of rats to foreign substances, which alter their normal physiological processes. The presence of granulocytes indicates a stimulation of the immune system (anti-inflammatory effect) which protects the rats against infection that might have been caused by chemical and secondary infections, or it could be attributed to an increase in granulocytes mobilization. However, after 28 days of administration of $K$. grandifoliola extract at $1000 \mathrm{mg} / \mathrm{kg}$ of $B W$, the significant decrease of platelets at the dose of $1000 \mathrm{mg} / \mathrm{kg}$ suggests an eventual decrease or loss of the protective nature of this extract at higher dose $[35,36]$.

Serum biochemical analyses were carried out to evaluate the effect of the extract on hepatic and renal functions and also on lipid profile. The evaluation of adverse effects of subacute oral dosing based on biochemical and histological analysis in experimental animal may be more relevant in determining the overall toxicity of any extract. When liver cell plasma membrane is damaged, a variety of enzymes normally located in the cytosol are released into the blood stream. Measurements of the activities of serum marker enzymes like ALT, AST have provided a powerful tool for the assessment of liver function [37]. The reduction in the levels of AST and ALT by the extract of $K$. grandifoliola after the 28 days of administration is an indication of stabilisation of the integrity of the cell membrane of the hepatocytes, keeping the membrane intact and the enzyme enclosed. ALT is a cytosolic enzyme found in very high concentration in the liver [37], and an increase of this specific enzyme indicates hepatocellular damage, while AST is less specific than ALT as an indicator of liver function. Estimation of the total protein is one of the most widely used means of measuring hepatocellular injury. Total protein measurements can reflect nutritional status and may be used to screen for and help diagnose kidney disease, liver disease, and many other conditions. The decrease in the serum total protein indicates that the synthetic function of the liver has been affected without associated liver disease. A significant decrease in the serum proteins clearly shows that the extract may inhibits protein synthesis in the rats although the values are still within the normal range ( 5.6 to $7.6 \mathrm{~g} / \mathrm{dL}$ ) as reported by The Rat Fan Club (2010). In this study the extract of $K$. grandifoliola increased significantly protein total, at the dose of $250 \mathrm{mg} / \mathrm{kg}$ without pass the normal range reported by The Rat Fan Club. This shows that the extract may modulate protein synthesis. Also, the levels of blood cholesterol, triglyceride (at 500 and $1000 \mathrm{mg} / \mathrm{kg}$ ) significantly reduced in the tested female groups, as compared to the control group, indicating that $\mathrm{K}$. grandifoliola has hypolipidemic [38] and hypocholesterolaemic effects [20]. Hypocholesterolemia can also be explained by the hypolipidemic effects of this extract. The hypocholesterolemia could also be the consequence of the hepatotoxicity of the extract. In fact, the liver is the main seat of the synthesis of blood cholesterol. Any violation of liver function may therefore inhibit the synthesis and subsequently reduce blood cholesterol levels. The increase (in this study no significantly at $1000 \mathrm{mg} / \mathrm{kg}$ dose) in serum AST levels may indicate cardiac involvement, of liver disease, or damage to internal organs. The results of histological sections suggest the involvement of liver and lung disease in this increase. Histologically, the liver in some females and males at a dose of $1000 \mathrm{mg} /$ $\mathrm{kg}$ shown vascular congestion and / or inflammation associated with vascular congestion; but do not suggest that they were related to treatment saw their presence in some satellites control (I). These vascular congestion and inflammation seemed however benign, since reversible in animals satellites (II) treated at this same dose. These results suggest a low hepatotoxicity of the extract at the lower dose of 250 and $500 \mathrm{mg} / \mathrm{kg}$. But in the higher dose of $1000 \mathrm{mg} / \mathrm{kg}$ of K. grandifoliola, the histopathological examination with hepatic cell damage was probably due to the presence of saponin in this plant [23]. Saponins are known to have deleterious haemolyzing effect on circulating erythrocytes [39, 40]. Again, liver congestion could be attributed, in part, to its role in biotransformation of xenobiotics. In the lungs the falveolar coalescence (which is evidence of rupture of alveolar walls a condition that can occur in conditions where air is entrapped in the lungs like asthma, emphysema, bronchospasm), lung congestion and Interstitial hemorrhagic (is examplified by conditions like pulmonary hypertension: increased pulmonary artery pressure due to compression of the lung vasculature by the collapsed parenchyma) related to treatment were observed in females and/or males. These pathologies observed in some animals may be due to poor feeding along the 28 days of treatment or were reversible, because they have a marked reversal of congestion and hemorrhage to near normal in male and female lungs with satellite control at $1000 \mathrm{mg} / \mathrm{kg}$. These results then suggest a toxic activity transient but sizable of the extract of $K$. grandifoliola on the lungs. Creatinine is known as a good indicator of renal function [41]. Any rise in creatinine levels is only observed if there is marked damage to functional nephrons [42]. There were no significant changes in the levels of serum creatinine and urea in the treated groups compared with the controls. It can therefore be inferred that the extract did not have any deleterious effects on renal function. All these results suggest the absence of major any deleterious effects on renal function; and cardiovascular risks factors [43] induced by K. grandifoliola.

\section{Conclusion}

Our results had demonstrated that the aqueous extract of stem-bark of K. grandifoliola possesses the lowest toxicity effects as indicated in our rat model. No deaths or signs of toxicity were observed in the rats that received the extract up to an oral acute limit dose of $2000 \mathrm{mg} / \mathrm{kg}$. The aqueous extract K. grandifoliola is safe for usage in traditional medicine. Higher doses should, however, be avoided. Since toxicity in humans cannot always be entirely extrapolated from animal studies clinical evaluation needs to be performed to precisely define advisable safe dosage for humans.

\section{References}

[1] M. Bnouham, F.Z. Merhfour, M. Elachoui, A. Ziyyat, M. Aziz, et al., Toxic effects of some medicinal plants used in Moroccan traditional medicine, Moroccan J. Biol. 2(3) (2006) 21-30.

[2] H. Inamul, Safety of medicinal plants, Pak. J. Med. Res. 43(4) (2004) 1-8.

[3] B.M. Wickramasinghe, Quality control, Screening, toxicity and regulation of herbal drugs, Mod. Phytomed. 2 (2006) 25-57.

[4] A.N. Ukwuani, M.G. Abubakar, S.W. Hassan, B.M. Agaie, Toxicological studies of hydromethanolic leaves extract of Grewia crenata, Int. J. Pharm. Sci. Drug Res. 4 (2012) 245-249.

[5] National Toxicology Program (NTP), Medicinal herbs, 2006 http://ntp.niehs.nih.gov (Accessed on: $12^{\text {th }}$ March 2013)

[6] World Health Organization (WHO), Guidelines on safety monitoring of herbal medicines in pharmacovigilance systems, World Health Organization, Geneva, Switzerland, 2004

[7] N. Suzuki, Complementary and alternative medicine: a Japanese perspective, Evid. Based Compl. Alt. Med. 1 (2004) 113-118.

[8] S.O. Awe, O.A. Olaijide, J.O. Adeboye, J.M. Makinde, Pharmacological evaluation of Khaya grandifoliola methanolic extract, J. Pharm. Res. Dev. 2 (1997) 20-23.

[9] J.D. Olowokudejo, A.B. Kadiri, V.A. Travih, An Ethnobotanical survey of herbal markets and medicinal plants in Lagos state of Nigeria, Ethnobot. Leaf. 12 (2008) 851-865.

[10] T.O. Odugbemi, O.R. Akinsulire, I.E. Aibinu P.O. Fabeku, Medicinal Plants useful for malaria therapy in Okeigbo, Ondo State and Southwestern Nigeria, Afr. J. Trad. Complement. Altern. Med. 4(2) (2007) 191-198. 
[11] J.M. Makinde, S.O. Awe, J.M. Agbedahunsi, Effect of Khaya grandifoliola extract on Plasmodium berghei berghei in mice, Phytother. Res. 2(1) (1988) 30-32.

[12] J.M. Agbedahunsi, A.A. Elujoba, J.M. Makinde, A.J.M. Oduda, Antimalaria activity of Khaya grandifoliola stem bark, Pharm. Biol. 36 (1995) 8-12.

[13] J.M. Agbedahunsi, I.F. Umeevuruo, T.O. Elufioye A.O. Adepiti, In vivo Interaction between Extracts of Khaya grandifoliola (Welw) CDC (Meliaceae) and Artemisinin in a Murine Malarial Model, Eur. J. Med. Plants. 3(4) (2013) 552560.

[14] S.O. Ijarotimi, J.M. Agbedahunsi, C.O. Onyeji, C.O. Adewunmi, Chemotherapeutic interaction between Khaya grandifoliola (WELW) CDC stem bark extract and two anti-malarial drugs in mice, Afr. J. Trad. Compl. Altern. Med. 7(4) (2010) 370-376.

[15] N. Njifutie, N. Njikam, Curative dose of Khaya grandifoliola stem bark for the treatment of gastric ulcer using rats, Pharm. Biol. 44 (2006) 152-155.

[16] U.A. Stephen, F. Abiodun, O.E. Osahon, Phytochemicals analysis and antibacterial activity of Khaya grandifoliola stem bark, J. Biol. Sci. 9(1) (2009) 63-67.

[17] F. Abiodun, F.P. Ching, A.A.O.E. Sunday, Phytochemical and anti-inflammatory evaluation of Khaya grandifoliola stem bark extract, Int. J. PharmTech. Res. 1(4) 2009 1061-1064.

[18] V.V. Bumah, U.E. Essien, J.M. Agbedahunsi, O.U. Eka, Effects of Khaya grandifoliola on red blood cells and bones, Phytother. Res. 19 (2005) 928-931.

[19] A.A. Adeyemi, A.A. Gbilade, Antianaemic activity of Spondias mombin and Khaya. grandifoliola aqueous extracts on rats, J. Pharm. Biores. 3 (2006) 94-97.

[20] V.V. Bumah, U.E. Essien, J.M. Agbedahunsi, O.U. Eka, Effects of Khaya grandifoliola on some biochemical parameters in rats, J. Ethnopharmacol. 102 (2005) 446-449.

[21] F.N. Njayou, P.F. Moundipa, A.N. Tchana, B.T. Ngadjui, F.M. Tchouanguep, Inhibition of microsomal lipid peroxidation and protein oxidation by extracts from plants used in Bamun folk medicine (Cameroon) against hepatitis, Afr. J. Trad. Compl. Altern. Med. 5(3) (2008) 278-289.

[22] F.N. Njayou, E.C.E. Aboudi, M.K. Tandjang, A.K. Tchana, B.T. Ngadjui, P.F. Moundipa, Hepatoprotective and antioxidant activities of stem bark extract of Khaya grandifoliola (Welw) CDC and Entada africana Guill. Et Perr, J. Nat. Prod. 6 (2013) 73-80.

[23] S.A. Ojokuku, W.O. Okunowo, A. Apena, Evaluation of the chemical composition of Khaya grandifoliola and Ficus capensis, J. Med. Plant. Res. 4(12) (2010) 11261129.

[24] U.A. Stephen, F. Abiodun, O.E. Osahon, Phytochemicals analysis and antibacterial activity of Khaya grandifoliola stem bark, J. Biol. Sci. 9(1) (2009) 63-67.

[25] J. Bickii, N. Njifutie, J.F. Ayafor, L.K. Basco, P. Ringwald, In vitro antimalarial activity of limonoids from khaya grandifoliola C.D.C. (Meliaceae), J. Ethnopharmacol. 69 (2000) 27-33.

[26] OECD Guidelines for the Testing of Chemicals, Section 4, OECDiLibrary (2008) 1-14. https://doi.org/10.1787/20745788
[27] T.J. Youmbissi, S. Djoumessi, C. Nouedoui, P. Ndobo, J. Meli, Profile of the group of hypertendus african black camerounians, Med. Afr. Noir. 48(7) (2001) 305314.

[28] J.T. Mukinda, J.A. Syce, Acute and chronic toxicity of the aqueous extract of Artemisia afra in rodents, J. Ethnopharmacol. 112 (2007) 138-144.

[29] O. Soa, A.E.A. Oaa, A. Dab, Antidiabetic and haematological effect of aqueous extract of stem bark of Afzelia africana (Smith) on streptozotocin-induced diabetic Wistar rats, Asian Pacific J. Trop. Biomed. 1 (2011) 353-358.

[30] A.C. Guyton, J.E. Hall, Textbook of Medical Physiology, 10th Ed., Saunders, Philadelphia, 2000

[31] S. Kafaie, S.P. Loh, N. Mohtarrudin, Acute and sub-chronic toxicological assessment of Nannochloropsis oculata in rats, Afr. J. Agri. Res. 7(7) (2012) 1220-1225.

[32] M.K. Gautam, A. Singh, C.V. Rao, R.K. Goel, Toxicological evaluation of Murraya paniculata L. leaves extract on rodents, Am. J. Pharmacol. Toxicol. 7(2) (2012) 62-67.

[33] P. Delves, S. Martin, D. Burton, Roitt's essential immunology, 11 th Ed., WileyBlackwell, Hoboken, NJ, USA, 2006.

[34] P.A. Tarkang, G.A. Agbor, D.A. Tchamgoue, L.R.Y. Tchokouaha, D. Kemeta, N.Y.S Mengue, Acute and chronic toxicity studies of the aqueous and ethanol lea extracts of Carica papaya Linn in Wistar rats, J. Nat. Prod. Plant Resour. 2(5) (2012) 617-627.

[35] I. Celik, H. Suzek, The hematological effects of methyl parathion in rats, J. Hazard. Mater. 153 (2008) 1117-1121.

[36] R. Aliyu, A.H. Adebayo, D. Gatsing, I.H. Garba, The effects of ethanolic leaf extract of Commiphora africana (Burseraceae) on rat liver and kidney function, J. Pharmacol. Toxicol. 2 (2006) 373-379.

[37] H. Hosseinzadeha, S.S. Shakibb, A.K. Samenic, E. Taghiabadib, Acute and subacute toxicity of safranal, a constituent of saffron, in mice and rats, Iran. J. Pharm. Res. 12(1) (2013) 93-99.

[38] A.C. Igweh, A.O. Onabanjo, Chemotherapeutic effects of Annona senegalensis on Trypanosoma brucei brucei, Ann. Trop. Med. Parasitol. 83 (1989) 527-534.

[39] A. Sofowora, Medicinal plants and traditional medicine in Africa, Spectrum Books Limited, Ibadan, Nigeria, 1993, pp.150-156.

[40] M.F. Rahman, M.K. Siddiqui, K. Jamil, Effects of Vepacide (Azadirachta indica) on aspartate and alanine aminotransferase profiles in a subchronic study with rats, Hum. Exp. Toxicol. 20 (2001) 243-249.

[41] N. Lameire, W. Van Biesen, R. Vanholder, Acute renal failure, Lancet 365 (2005) 417-430.

[42] M.R. Law, N.J. Wald, A.R. Rudnicka, Quantifying effect of statin on low density lipoprotein cholesterol, ischaemic heart disease and stroke: systemic review and meta-analysis, Brit. Med. J. 326 (2003) 1419-1423.

[43] The Rat Fan Club, Normal laboratory values, 2011 www.ratfanclub.org/values.html (Accessed on: 23 ${ }^{\text {th }}$ February, 2011). 